\title{
Jathilan: Between the Javanese sacred rituals and per- formance in tourism attractions
}

\author{
Galuh Pawestri* \\ Universitas Gadjah Mada, Yogyakarta, Indonesia
}

\section{Keywords \\ Shamanism \\ Tourism \\ Attraction \\ Society \\ Jathilan}

Received: 8 August 2019

Accepted: 5 September 2019

Published: 31 October 2019

\begin{abstract}
This article describes how the so-called sacred activities conducted by Shamans are being and should be under the spotlight of the tourist attraction. In Indonesia, there are so many varieties of tourism places and events to be experienced. Traditional events exclusively exist only in Indonesia, such as one of Javanese tradition or Jathilan, etc. Jathilan is purposely conducting to entertain the traditional troops in Java when they were going to a battle, but now it is pure entertainment for the society. In Indonesia, the world religion and the indigenous religion or traditions are coexisting in society. Jathilan tradition could be one example that Indonesian culture could maintain to survive, though it is not as popular as before. Using a literature study and personal experiences in watching Jathilan performances, this article aims to show that sacred activities used to attract people are not losing their sacredness at a certain point. Taylor's article about the sincerity and authenticity of cultural tourism used to support the point of view of this discussion. How the Jathilan still maintained as a sacred performance in the tourism attraction. Even the tradition has been through to certain modifications; they could maintain their own identity and sacredness for society to enjoy. This study suggests the society to help the tradition have its place in tourism to protect the cultural heritage in Indonesia.
\end{abstract}

(C) 2019 The Author(s). Published by TAF Publishing

\section{INTRODUCTION}

A study of religious practice is somehow tricky. Due to the broad definition of religious practice or religion or as I commonly attached also to the term of tradition, scholars should be thorough on what they or we purposing about. Taking example of the term shamanism in the religious study scholarship which is in fact is the oldest kind of religious practice or activity found in the world. As Eliade explained in his article that shamanism is a religious tradition in a broadest sense $(1964, \mathrm{xix})$ so that make a religious practice does not promote such a rigid margin to define. Many scholars in talking about shamanism were only focusing on what the shaman do most of the time which is being possessed and curing the others. Indeed, they are capable in doing things which common people could not and being possessed by the spirits are significant enough to be considered them as the special one. In fact their capability is also beyond that. As in this article, I use an Indonesian tradition, especially a tradition in Java Island as an object of shamanism tradition which provides the insight toward its position and values between sacred and performance in modern tourism.

Tourism has brought religious practices or tradition into a more mundanic space. It helps the practices to open the opportunities to every person experience the values. The tradition which I will be focused on is called Jathilan. Jathilan has two main functions in the society or community who conducts it, which are as entertaining medium and spiritual fulfilling medium (Bariscil, 2017; Irianto, 2015). Thus through tourism, people who witness the performance who are not a practitioner, a follower, a believer, and such, could build connections. As this article approaches the tradition as a form of shamanistic practice which related to the tourism element, it will contribute as an additional perspective on how religious practice combines with modern needs

\footnotetext{
*corresponding author: Galuh Pawestri

†email: galluhpawestri@gmail.com
} 
without deteriorating the sacredness of the practice. The tradition Jathilan has another term which are Kuda Lumping or Jaran Kepang, in Java, means as flat horse since its shape is flat and its made by plaited wooden depicted a horse without its legs while in Baliness tradition it is called as Sang Hyang Jaran. Bandem (1995) mentioned that it is performed within two up six individuals whom also accepting the divines possessed with incense, chanting, prayers but in Java there could be more. In the stage of the play there are sets of flowers which Javanese used to be one of the offering to the ancestral spirits. Jathilan originated in Java Island and might be related to Pangeran Diponegoro's era which is the Dutch Imperialism era. Historically, based on the news it was used to entertain the traditional troops before they get in to a war. There are two troops depicted to be fighting at each other while the gamelan or traditional music instruments are played ${ }^{1}$. But reports are pointing which pointing that the performances might be also influenced by the Hinduism practice because of the Sang Hyang Jaran performance in Bali. Hinduism in Indonesia is one of the oldest religious practices which still exist and have Bali Island as their main place. Another element that shows the Balinese Hinduism in the performances are the flowers offering to summon the spirits to come (Kuswarsantyo, 2013; Weng \& Yang, 2016).

Uniquely, several minutes into the action, the dancers are going into a state of trance. Each possessed dancers could perform an actions which common human is impossible to do, such as eating grass, glass, or flowers, walking through the fire coals. Meanwhile the dancers (the spirits) dancing, the Shaman will take cares the area and their needs. The setting of the performance is usually in a wide area where they give a space between the dancer and the audiences whether in a field or in a small park. Though the space between the performance area and the audiences is not too far, it is enough for the dancers to roam around. Sometimes there are no material boundaries between the two (fence, separating line), but the audiences already have their own knowledge about how close they could may get positioned. Jathilan is actually an epitome of the term "dancing with the spirits" because the dancers are believed to be possessed by the spirits and dance following the music.

In this article, I am aiming to discuss about the other type of shamanic practice which still exists in Indonesia, to see its values as a religious tradition and a tourist attraction. Jathilan has a figure of shaman or in Javanese they called as Pawang, so in that case I argue that it could be in term of cultural and also a religious tradition. The figure's roles are to conduct the ritual to call the spirits and asking for their permission. They have to take care of the dancers if they get possessed by spirits because it is often to get more intense as hour goes by. There are some cases when a "naughty" spirit goes wild and does not caring the invisible boundaries between them and the audience. One of the shamans' roles is to control them to be stay in the "stage" so they do not bring harm to the audiences. In addition, since the Jathilan used for entertainment purposes nowadays it is also performed as a tourist attraction. The traditional and cultural identity here is seen by the Indonesian for touristic interest so the value of its sacredness is interesting to be discussed about.

Based on that background this research's significance is also a challenge toward the religious scholarships about the jeopardize of sacredness or religious values by the modernity. As in this research object is the Shamanistic traditional performance seen as an art performance equal to the touristic elements. A lot of scholar point out the problematic issues arisen due to modern influence or development. However, in this research, I humbly propose to see the development process of old religious tradition within the modern society in a different perspective. It takes the process of understanding the practice and its relation with the surround environment to see the values itself. In this case, to look and understood the practitioners' and the publics' relation and function in the performance or the practice.

\section{LITERATURE REVIEW}

Picard (1990) explained in his article entitle as "Cultural Tourism in Bali: Cultural Performances as Tourist attraction" that Bali purposed a way to answering the "Tantangan Pariwisata" or the challenge of tourism which is the Pariwisata Budaya (1990). In this way, Bali made their culture to be the attraction in tourism which mostly projected to have a foreign tourist. At firsthand, the people itself aware that the view maybe bring harm to their culture. Eventually, they realized that in the way of introducing their culture exactly bring an opportunity to stimulate their artistic creativity and also their pride of their cultural identity (1990). Latter on Picard discussed about how the Balinese traditional dances are different from what western tradition seen as an art because in Bali, the dance are done by the "specialist" accordingly to its purpose. The purpose is to serving to Gods and community (1990). I think the differences between eastern and western perspective about the art per-

$\overline{1}$ https://bit.ly/3crA6yp. It is a blog contained informations about Banjaroya Village Tourism. Banjoraya village is located in Kulon Progo, Yogyakarta. There are many tourism places and traditions attraction comes from the village to inform the internet citizen about the area. 
formances are appealing because of that then the culture product from each traditions are valuable. That is what the Balinese traditional art performance is selling for. But then, as Picard argues that Balinese authorities had successfully to face the challenge of the conversion from the traditional dance into a tourism attraction (1990). This is intrigued me to see how if the authorities of Yogyakarta could do the same action towards Jathilan. As we see that the Bali tourism attraction make such a way to promotes their culture to the global while they still be able to preserved it as their own identity.

Another thing that Picard has pointed out which I agree and I see the similarity between Balinese traditional dance and The Jathilan. That is when the Balinese traditional dance is being performed then they do not expect the audiences only from the human but also from the sacred realm such as ancestors, spirits, and Gods (Picard, 1990). The similarity between both is actually a concept which is very much familiar and common in Indonesians indigenous traditions. In detail, Picard explained that Sanghyang Jaran means a trance exorcistic dance which used a horse-like attributes and mimicking the action which the spirits wanted the dancers to do (Picard, 1990). Thus this is an obvious example which everyone could recognize. As Kathleen M Adams says that Balinese traditional dance is an artistic creativity (Kathleen, 2011), the Jathilan also should be include in the term as both has similarity and traditional values which are emerged from the local people or community. Next article are written by Sutiyono which also proposed an insightful article about how Jathilan influenced by the globalization. Sutiyono explained that the Jathilan performances are a form of society's belonging and it's still are. However, due to the globalization which brings capitalization and industrialization, the Jathilan performances now have several changes. First, it used as a tourist attraction and the duration of the performances which usually take up to six hours to become only one to one half-hours. Second, they used dangdut ${ }^{2}$ and campursari ${ }^{3}$ instead of traditional instrumental music background to play while it performed. Three, it used to be perform directly, but since there are technology development the performances are now recorded in a digital form thus it makes people could watch it repeatedly without being there (Sutiyono, 2013). In addition, Sutiyono mentioned that there are positive and negative side effects from globalizations toward Jathilan which is also happened in the other similar traditions or rituals. The positive effects are it could motivate the performers to become more creative and also it gives a space to grow. The negative effects are the sacred ritual could become profane ritual. It become commercialized and decreasing the traditional values of it (2013). Later, Sutiyono also mentioned that in the field, there are some additions of the instruments used in the performance. It is an electronic keyboard, drum which is sound so modern (2013). In the other hand, the Jathilan performances in rural area are still having the local wisdom and local genius which a lost element in the city performances. Thus, it needed to be taken care of to preserve or to maintain the values in the stream of globalization (2013).

The literature written by Kuswarsantyo (2013) explained how the Jathilan performances developed in tourism era. It is changes several things after it become an object of tourism. Up until there is more Jathilan group emerged to fulfill the need of tourism attraction (Kuswarsantyo, 2013). It discussed the history of the Jathilan based on its demographic condition, due to its different areas then the terms and the function of the performances are also various (Sutiyono, 2013). It is also explained that the changes in Jathilan performances have happened in two spheres, internal and external. The internal sphere is from the insiders' behavior or perspective toward their culture and the external sphere is from the outsiders' influences (Kuswarsantyo, 2013). There are four main functions promotes by Jathilan performances. First, Social functions which Kuswarsyanto mentioned that the performers in doing the training of their play are also to kept in touch with the others members. It is also what makes Jathilan tradition are unique because it became a system of social binding (Thompson, 2013). Second, Ceremonial function, the performances are at least played every Sapar month in Javanese traditional calendar, offering from the society and also the trance element brings the mystical nuances in the performance (Kuswarsantyo, 2013). Third, entertain function, when modernity and the education of the society develop, the local wisdom values which Jathilan promotes may be decreasing. The performances are projected to be under the spotlight for viewers demand. Sometimes it takes the origin elements of it, such as the duration, the serving, the attributions, etc. Up un-

$\overline{2}$ Dangdut is a local music genre which has unique tempo and pattern. It popular in through every level of society but it more attached to the middle-bottom level of society. It usually, has women singer with local language lyrics. The signature of the music is from kendang, a traditional instrument, and it makes audiences dances along with the rhythm.

3 Campursari is a new genre of traditional music mixed with the modern instrumental such as keyboard and drum. It is originated from the Javanese culture. 
til the trances state are seen as not a fully necessary anymore (Kuswarsantyo, 2013). Forth, the Education function, when the Jathilan are performed by the younger generations it would become a strategy to pass the tradition to the descendants. In addition, the younger generations tend to add their-own preferences to the performances and it gives a new style to it (Kuswarsantyo, 2013).

In addition, Susanti write a research which talked about the aesthetic values of one type of Jathilan called as Jathilan Tuo in (Susanti, 2015). Based on the article, the Jathilan Tuo performed by old which effecting the rhythm to be slow in contradictory to common Jathilan tradition. In common tradition, it is performed in an energetic way and high speed tempo. It is one of the aesthetic value of the Jathilan Tuo (Susanti, 2015) By this article, I understand that the values of the tradition either it is performed in a hectic or in a stoic way, the spirit possession element are vital. It shows how the performers devoting themselves toward the dance and having connection toward the sacred and projects it toward the audiences who enjoy the art.

Another mind opening research conducted by Wibowo in 2020. Tittled as "Perancangan Film Dokumenter Tari Jathilan Yogyakarta" (trans: Planning Documentary Film of Jathilan Yogyakart Dance ), it aiming to capture and relay the magical value of the performance which considered as a common tradition by the local thus it absorb the influence of the tradition (Sutiyono, 2013). By this research also, the importance of old tradition could be transmitted toward the modern media which is film after doing a proper data collection done by the devoted researchers. I support the idea that modernity also brings good values toward the old religious practice if there are legitimate connections and intentions between the elements. Furthermore, it is the originality of my research which is extracting the example of how legitimate connections and intentions between the elements involved in the religious practice or tradition as a touristic attraction which does not lose its sacredness.

The last work I used for expanding my perspective in this research is written by Mulyani titled as "Peranan Kesenian Jathilan Terhadap Pengembangan Pariwisata di Kabupaten Kendal" (Trans. Jathilan Tradition's affect toward Tourism Development in Kendal District) on year of 2017. It is regarded the tourism development as a tool or medium for society to preserved the Jathilan traditions. Even though there are changes happened in the function of the tradition from a protection to become a entertaining performance, Tourism place offered its space for the Jathilan as a pack- age thus there is chance for the local community to keep maintaining the tradition as a part of their culture identity (Mulyani \& Pramusinto, 2017). This article gives additional perspectives about tourism space which open the opportunity for the local tradition to maintained. It is a insightful perspective as it is also supporting my argument. However, in my research, the religious value perspective is the focused approach. Meanwhile, in Mulyani's work, the function of the tourism space as a medium for the development for the Jathilan is the main theme.

A lot of articles have a similar point in explaining the phenomena relating to Jathilan, which is the changes due to social development. Their attributes, their play, their way of conducting the play, etc, are change. The main focused in this article is when it becomes an entertainment performance which historically it already has this function in the society, are the Jathilan performances loss its sacredness and become an object of modernity or only a product the society sell. However, since the globalization also has been flowing in to Indonesia, the system of entertainment also expand. Here in touristic place also happened to have Jathilan as their attraction product. The performers play the Jathilan for people in the touristic places to enjoy. To complete the discussion and the framework, this research adds the religious perspective in seeing the Jathilan performances as a tourist attraction using the authentic and sincerity value by John P. Taylor.

Taylor explains the values of authenticity and sincerity in "cultural tourism" which taken from the example of what Maori community in New Zealand on their tourism space called as Marae. Authenticity is more likely equated with the originality, which done in the past, it is the old or the traditional version of the re-productions program (Taylor, 2001). It give the vibes of the origin had been done in the past. It is seen as their real identity as the original one which considered by the tourism as a pure one. Many western tourism perspectives take this way to considered how valuable or how original the culture or the object of the tourism is. But then as the strategy to gives a traditional value to the culture, a strategy to see the projected culture similar to what the consumers' culture is important. Taylor stated that

The capacity of this strategy ${ }^{4}$. Temporal distance between the viewing subject (red: tourist) and the consumable objects (tourism-generated aspects of "traditional" Maori life) provides an important addition to the value of tourism sites and destinations in New Zealand (Taylor, 2001).

$\overline{4}$ Equating the traditional with the pre-contact or pre-encounter with other culture (Taylor, 2001) 
The projected culture or the resident culture or the object as well as the consumers or the tourists, should have such perspectives that both have the equal values as a culture. Therefore, both could have a reciprocal behavior. Later, Taylor also explained that the tourists are visiting the place or the culture to have certain encounter with it. As he used the phrase of tourism makes people in the zone of contact (Taylor, 2001), it makes them capable to reach the culture or to have such experience. They want to have different experience from being in their own culture. But then following problems are arises. As Taylor mentioned that:

The moment that culture is defined as an object of tourism, or segmented and detached from its indigenous sphere, its aura of authenticity is reduced (Taylor, 2001).

Every culture promotes its own aura which makes them authentic. Or it could be said that it is their authenticity which makes them has their own aura. This is the point which cultures tourism would "sell" or introduce to the tourists. Mostly, western tourism would is projecting the authenticity as the values in the tourism. Thus, the culture tourism is popular. But when it becomes an object for tourism industry, there are rules, limitation, standards which follow the interest of the culture. Then the projected culture would adapt or change slightly or hugely to follow the interest of the consumers. On the other hand, this influence also could be seen in the opposite perpective. The demand from the tourist of the genuine or the authentic version of a culture or a tourist product, are a positive interest (Taylor, 2001). This way, the projected culture would make such improvement of their selves. The improvement here is relating to their identity as a culture. So, I regard to looking from that Taylor mentioned about the "Sincerity" term which comes from inside of the performers or the culture's society. Then, when they show the true version of their culture, the tourists can chose to have interaction to it. A more intensive interaction is build, not only consuming the culture as an object but also learn a new culture. As Taylor explained that the sincerity on the tourism is implying the interactive sharing of experience (Taylor, 2001). Both elements (The projected culture and the tourists) have direct interaction or encounter to shares values.

The authenticity strategy is more appealing to the modernist while the sincerity is allowing the communication of localized identities to be happened (Taylor, 2001). This happened because the modernist tends to objectifying others without any further study as a culture. As Taylor explained that type of cultural experiences tourism which serve the contact between the performers and tourists are not much appealing for the international tourist. They are not interest in having a further contact to the performers because they have such differentiating the tourist and performers (.idim). However, when a cultures that there is a chance to have a more intensive experiences with, it change the industry of tourism because, the culture will organize themselves since they become aware of their own identity. Another problems arise about the Authenticity. It is here that the terms authentic and traditional are often to be in the same table. It identified the ritual performances which also often to be seen as the keys to the past (Taylor, 2001). So, there is an attempt to erase the present which brings the guest to see the front region of the performances without an intention to hide the "real" culture in the back region (Taylor, 2001). In fact, the culture should present as the way they are. However, the act of hiding or make the real culture in the "back stage" is risky. As the performance or the culture has back-stage, there is front-stage which they present to the tourists or consumers. As Taylor said here they superficially create the culture as an object which arguably a real culture. The authenticity here is reached by a simulation or a mimesis action (Taylor, 2001).

Further problems are still following. As Taylor explained "The stage shows" are presented as the "personality" and the lifestyle of all society. Even though it is only the marketing strategy to present the standardized version as a representative of a culture, but it tends to create the tourist expectations at certain point. This marketing strategy can end up as an act of exploitation of the culture as it defined the identity of the culture (Taylor, 2001). Behind that also there is a paradox whether the agency and the sensibility of the individual performers are doing an "acting" when they were "on the stage" or not (Taylor, 2001). In this step, the issues are also significant. Even though they are the performers but when they act to present their culture without being there sincerely as a culture presenter, it makes the culture aura or authenticity loss. The sincerity point makes the difference. With that point, they can present their culture and their identity to the tourist and built such communication or relation to them. Taylor exampling that due to the international tourists, the Maori culture will be presented in a "staged authenticity" form or version but this makes the contact between the tourist and the local identities lost. The tourist does not have a dialogue toward the culture because it is becomes "strangers" (Taylor, 2001).

As Taylor mentioned that the intensive communication or relation between the culture performers and the tourists can be called as "Cultural exchanges" or "interaction experiences". This process is helping the tourists to have a real interaction with cultural product and is more genuine and 
educational. It brings two advantages which are (1) The tourists can "absorb" the cultural experiences in tourism, (2) the culture can get benefits. Such as they could give the tourist their real values to which had been limited by the industry and media (Taylor, 2001). By here, sincerity takes more steps than the authenticity does. It brings the Local community perspective towards themselves and also the "Others" which is the tourists (Taylor, 2001). By taking the sincerity strategy, the culture and the tourist are having their own positions, not only as an object and a consumer. The sincerity not the opposite of the authenticity, rather it is where the tourists and the performers meet. And here is the authenticity that can be redefined in a newer term of the local values. The moments when the interaction between the tourists and the culture meet, that is when the cultures' values is being perceived (Taylor, 2001).

Taylor articles shows that the sincerity in cultural performances in tourism is significant. By sincerity, the local community or the performers have their time to do their tradition as their ways and also to promote it. By applying the sincerity strategy also could help the culture performers to have their own contact to the culture in which they perform. Sincerity also bring light to the culture and tourism because it helps the culture to brings out their identity but also help the tourist or "the other" or the outsiders to enjoy and following the tradition values or worldviews as a piece of knowledge or at least as an cultural experiences.

\section{METHODOLOGY}

For research methodology I focused on literature study and completed it with the observed sources from my personal experiences in watching Jathilan performances and oberving the interaction between dancers, the Pawangs, and the audiences. The literatures objects here are accessed from online sources which are e-book, e-journals which discussing about traditional art performances relating to tourism. In addition to that website blog which showing the updated data about Jathilan are discussed to determine the online behavior from the individual whom interested in this topic.

The e-books and e-journals accessed in the google scholars and online journals which several of them are provided by the Universitas Gadjah Mada such as J-Stor. The literatures are chosen by their relation with this theme and also the one which gave another insight about the theme. An online blog also used to add the shreds of supporting ideas on how the Jathilan be presented. There is one blog which contains the local tourism place in Yogyakarta, especially in $\mathrm{Ku}$ lonprogo which apparently dedicated its one page on local
Jathilan performance. The blog is accessed in 2018 for completing the online data about the tradition which aiming to promote the local tourism spots in Kulonprogo. The blog title is https://dewabara.wordpress.com

The last and the main method is direct observation which I use is a personal experience in encountering the Jathilan performances. As a local resident, I added the personal knowledge and experiences in watching the Jathilan performances. The recent experience I had was on the year of 2017 in my neighborhood, located in Tebing Breksi, Prambanan. Tebing Breksi or Breksi Cliff Park is a new tourism spot in Yogyakarta. It was actually a former Breksi stones mine which now developed by local community as their asset. They make certain carving on the huge stones, there are dragons, Wayangs' figures, and animals. The stones dimensions are huge so make it creates more majestic nuances because the traditional values are on it. The Jathilan performance was held in the main stage which made as a cavity sided by the stones. The audiences were around them following the form of the audiences' seat made by stone. There, the interaction between audiences and the performers are significant to be discussed about.

\section{RESULTS}

As Jathilan is an art performance which has a sacred nuance in it sometimes it relates to what people call as magic. The sacred as Eliade (Pals, 2009) explained that

"Archaic peoples define the sacred as the sphere not of society, but of the supernatural-the realm beyond eartly life, full of changeless perfection, order, power, and beauty: the dwelling place of the ancestors and the Gods."

Jathilan brings the spirits who are living in the sacred realm to the world and entered the body of the performers. As mentioned that in Javanese, there are two types of spirits, which are spirits who live in the human world and in the upper world. When the Jathilan performers get trances, there are two possibilities of possession which happened from the world view (Astuti, 2015). The belief of the spirits and the possession are the strong element of the Jathilan tradition. The performers are believed to have possessed by the spirits and dance along with the music. While the Pawang or the shaman supervise and control the play, the spirits who are taking places of the performers are dancing. This tradition is an evidence of the local belief about the sacred and the mundane world. Both being connect in one place and space. Even though it is a tradition from generations but it is still promotes the same world view.

As I watching the Jathilan performance in Tebing Breksi, the audiences were spread not only in the audience's seat but 
also in the stage where the music instruments player were sat at, in front of the audience's seat, and also in side of the shamans seat. Actually, the main shaman's seat was only a simple carpet or in Indonesia, especially Java, it called as tikar. The audiences seemed to be not bothered by the hectic of the dance performances. They were enjoyed and be able to following the dances with their vision. They gave reactions when the one of the dancer whom was already in trance state had his body thrown away with his Jaran. Such reactions were constantly expressed when they got startled. As the other dancers were at their own pace, all of them were still been able to follow the rhythm of the musical instruments. While, the dancers (with the spirits) were expressing their-selves, the main shaman or Pawang were interacting with the audiences. With a cigarette in his hand, he walked away from his seat, slowly towards the audiences while the assistant shamans were spotted in different side to cover the area. The Pawang was easily to be seen by his outfit which was all black and it was a traditional male outfit, plus the head cover from the traditional fabric. He randomly sat beside audiences and gave them shake hand and talking for awhile then he moved on to the next side of audiences.

By here, I observed that the interaction between the Shamans, the dancers, and the audiences are intensively built. Here is the performance are not only conduct by the shaman and the dancers but also the audiences. With a little chat with the other audiences, I observed that they aware that the dancers are in a trances state or possessed by the spirits. They do not fear of it but acknowledging it as their culture. But then the audiences were predominantly local tourists. I am assuming this was because the place of Tebing Breksi is a new spot so they still did not have a chance to promote it internationally. The audiences are random. There were full member family, couple, groups of friend. Based on their appearance, it was easily to be identified that they whether came from urbans and villages. The audiences from urbans were more sophisticated in fashion while from the villages were more casual since they were only come from several minutes in the area.

The songs which played by the players are in Javanese but it mixed from the original traditional one with the campursari which is accounted as a modern version of Javanese genre. The original traditional music usually has moralistic and motivational lyrics in poetical way which very different with Campursari. Campursari usually has more nuances such as love, tragic story, and mundane problems with frontal way of written. This elements' change is results of the society's changes due to modernity. The lyrics are be- coming more acceptable or easier to follows which is considered to be not conservatives more modern. But the similar things both genres still have are the traditional instruments, kendang.

Another part that Jathilan promotes is the development of their attributes such as their wardrobe when they play. They still following what their older generations do to conduct the tradition. In the other hand, the outfit of the performers is only as casual as they could due to their fund. Thus shows that though they do some changes or some adaptation of their lifestyle, but they still conduct the play as before. They play it as if it as their former's way to play. I outsider perspectives, there are elements which still survives. It is the trances process and the Pawangs' roles. There are no Jathilan performances if there are no Pawangs included. As in Breksi, the Pawangs were there supervising the play. Though they not only sat back in their own respective seat, but they control the players as they going around to keep the player and the spirits to stays in the stage.

\section{DISCUSSION}

Tourists are tends to find a new experiences which they could not create or have within their own circle. Jathilan serves a different aura since it shows an art performance with the spirits. The changes in the performance are the way of surviving the development. When society changes or develops, their products are following the path. The sacredness in the Jathilan are un-arguably still promoted within the performers because they have their values linked down to generations. According to $\mathrm{Zhu}$, the tourist also should perceived the object as the other and are purposing to have experience the culture out from theirs, that is when they put an interpersonal orientation of authenticity Zhu in 2012. From the tourist point of view, the sacredness which I argue that contained within the sincerity of the tourism performers are exist.

The cultural tourism here is the main point in which this strategy can corrupt the sacredness of Jathilan performances, or not. As Csapó mentioned that cultural tourism is an activity of entertain, educating, or experiencing other culture or cultural attractions which combining the art, natural, social heritage, history of a place (Csapo, 2012). The experience of the tourist in enjoying the Jathilan performances are relating to their interest in experiencing the sacred performance which connects the human with the sacred. The strangers, the outsider, the other, or the tourist here are experiencing the sacred ritual and performances different from what their culture has. However, the insider or the cultural society which already familiar with the tra- 
dition are still having their time to enjoy the performances as an educating entertainment or even merely a time-killing entertainment.

The problems when sacred rituals or performances are perceived as an object, Yampolsky explained that by making their culture as profane as possible is the way of protecting them for being an object of desacralization due to legal religions stated by the government (Ya mpolsky, 1995). Somehow this strategy is succeeded because on that way their traditions are survives and could be conducts but still there are certain things followed. For example, the time when they do their tradition and the place where they play or shows it, must follows the regulations or the orders, if it become a tourism attractions in exact. The local community or the practitioners' roles are very much giving influences on how sacred or sincere or authentic is their traditions. As long as government gives an adequate portions on the traditions organizations to their practitioners it would be develop and become beneficial for both sides.

Moreover, looking on how the boundaries between the Shamans, the dancers, and the audiences, Jathilan should have an opportunity to make its name in the tourism attraction. The uniqueness and the traditional identity there are still vividly projected. They has this firm to preserve their cultural heritage. Even to their youngsters who are not familiar with this tradition due to modernity. But with this kind of event or opportunity, the Jathilan performances are going to public and making its way to become more acceptable in their area. I think that the local government also has to have their own supportive program in promoting and preserving this tradition. This actions would give stimulation to the tradition to be survives between the modernity.

\section{CONCLUSION}

The sacredness of the Jathilan are there from both sides, first, from the performers or the Pawangs' side and second, from the tourists or the consumers' side. As the Pawangs and the performers are still conducting the tradition in their ways and still believing on what the performance is purposing, the sacredness still surrounds. Though it is an object of tourism attraction, the doers' perspectives are significant to be account. Then the tourists or the consumers' point of view about the performances are up to point where the performers could not be criticize of. Here I mean that how the tourist or the consumers perceived the performances as sacred or not is on their own perception. Whether they see the Jathilan as a sacred performances relating to the spirits and the human connection or only a possessed depicting art performance, the sacredness there are up to their meaning giving process.

\section{LIMITATIONS AND RECOMMENDATIONS}

This study has some limitations, hence, its findings must be used with caution. Specifically, this study narrates personal points of view of author, hence, for lending authenticity and credibility to these findings, this study must be carried further in future.

Based on what I observed in the field, they still have the sacred values in doing the performances. After all, Jathilan is an art performance involving the spirits or the sacred realms within. As long as it preserved as the Pawang preserved it, then the sacredness behind the tradition would not erased by the predicate of being a tourism attraction. By this research also, I implicated that the process of preserving or maintaining the tradition value is not a single handed by the performers but also the give the adequate space for them to express the sacredness within the modern stage where they projected it. I explained that though tourism can corrupt the sacredness of the shamanistic tradition. However, to connect with it helps the preservation of the sacredness. Even without being a follower or a believer as tourist's interest are being entertain not to have their personal spiritual need fulfill.

\section{REFERENCES}

Astuti, R. K. (2015). Unsur magis dalam jatilan dan relevansinya terhadap pemahaman akidah (Studi kasus di desa wonorejo kec pringapus kab Semarang) (Unpublished doctoral dissertation). State Islamic University of Walisongo, Semarang, Indonesia.

Bandem, I. M. (1995). Performing arts of Indonesia (Performance education and archive). Oxford, UK: Oxford University Press.

Bariscil, A. (2017). Some aspects of the competitiveness of Turkish regions and their tourism industry the example of Ardahan. Journal of Advances in Humanities and Social Sciences, 3(6), 311-323. doi:https://doi.org/10.20474/jahss $-3.6 .3$

Csapo, J. (2012). The role and importance of cultural tourism in modern tourism industry. In Strategies for tourism industrymicro and macro perspectives. London, UK: Springer. 
Irianto, A. M. (2015). Mengemas kesenian tradisional dalam bentuk industri kreatif: Studi kasus kesenian jathilan. Humanika, 22(2), 66-70. doi:https://doi.org/10.14710/humanika.22.2.66-77

Kathleen, M. A. (2011). Everyday life in Southeast Asia. Bloomington, ID: Indiana University Press.

Kuswarsantyo, A. (2013). Jathilan art: Form, function, and development (1986-2013) (Unpublished master's thesis). Education of Dance Art Program, Faculty of Language and Art, Universitas Negeri, Yogyakarta, Indonesia.

Mulyani, S., \& Pramusinto, E. (2017). Peranan kesenian jathilan terhadap pengembangan pariwisata di kabupaten kendal. Gemawisata: Jurnal Ilmiah Pariwisata, 13(1), 56-70.

Pals, D. L. (2009). Introducing religion: Readings from the classic theorists. Oxford, UK: Oxford University Press.

Picard, M. (1990). Cultural tourism in Bali: Cultural performances as tourist attraction. Indonesia, 6(49), 37-74. doi:https:// doi.org/10.2307/3351053

Susanti, W. (2015). Nilai estetis pertunjukan tradisional jathilan tuo di desa kabupaten Magelang. Jurnal Seni Tari, 4(1), 132-140. doi:https://doi.org/10.15294/jst.v8i2.34750

Sutiyono, S. (2013). Mengenal dan memahani seni tradisional jathilan di era global (knowing and understanding Jathilan traditional art in global era). In Paper presented in a Workshop and Festival of Traditional Art themed Existency of Traditional Art in Global Era, Yogyakarta, Indonesia.

Taylor, J. P. (2001). Authenticity and sincerity in tourism. Annals of Tourism Research, 28(1), 7-26. doi:https://doi.org/ 10.1016/s0160-7383(00)00004-9

Thompson, E. C. (2013). Everyday life in Southeast Asia. New York, NY: Willey and John's Sons.

Weng, H. Y., \& Yang, C. H. (2016). Culture conservation and regeneration of traditional industries derived by tourism factorycase study of Kwong xi paper factory in Taiwan. International Journal of Humanities, Arts and Social Sciences, 2(5), 172-180. doi:https://doi.org/10.20469/ijhss.2.20003-5

Yampolsky, P. (1995). Forces for change in the regional performing arts of Indonesia. Bijdragen Tot de Taal, Land-en vVlkenkunde(1), 700-725. doi:https://doi.org/10.1163/22134379-90003035 